\title{
Recognition of the Iron Bacteria "Siderocapsa" as Arthrobacters and Description of Arthrobacter siderocapsulatus sp.nov.
}

\author{
G. DUBININA* AND A. V. ZHDANOV \\ Institute of Microbiology, USSR Academy of Sciences, Moscow, USSR
}

For the first time strains of Siderocapsa eusphaera Skuja, A and G, have been obtained in pure culture from lake water. The morphological variation of these strains exceeds the species distinctions of the previously described members of the genus Siderocapsa and those of the closely related and little studied other members of the family Siderocapsaceae, such as Siderobacter Naumann, Sideromonas Cholodny, Sideronema Berger, Ferribacterium Brusoff. Studies of the developmental cycle and physiology have shown that the newly isolated, Siderocapsa-like bacteria belong to the genus Arthrobacter of the family Corynebacteriaceae Cohn and Dimmick. The type species of this genus, Arthrobacter globiformis, and also the species A. citreus and A. simplex have been shown to be capable of oxidizing manganese and iron, thus forming morphological structures characteristic of Siderocapsaceae. It is proposed, therefore, that the family Siderocapsaceae be abolished as an independent taxonomic entity and that the naturally occurring bacteria so far described as species of Siderocapsa be considered growth forms of Arthrobacter species developing under specific conditions of habitat. Strains A and G of Arthrobacter (Siderocapsa) are regarded as belonging to a new species for which the name Arthrobacter siderocapsulatus is proposed. The strains have been deposited in the All-Union Collection of Microorganisms and have been assigned the numbers BKM-B N 1122 and BKM-B N 1123, respectively. Strain BKM-B N 1122 is designated as the type strain of $A$. siderocapsulatus.

The taxonomy of the iron bacteria is based entirely on morphological characters as established by microscopy studies of naturally occurring material. (This was chiefly a result of the lack of reliable cultivation methods and the absence of pure cultures of most iron bacteria.) Ascribed to the iron bacteria have been organisms capable of depositing ferric or manganese oxides irrespective of the physiological significance of this function for the organism itself. The term "iron bacteria" must, therefore, be regarded as ecological rather than taxonomic.

Within the morphologically heterogeneous group of iron bacteria, the encapsulated unicellular forms have been included in the family Siderocapsaceae Naumann. They have been divided into several genera depending on cell and capsule shape; the existence of some of them is questionable (20). Members of the genus Siderocapsa Naumann are most widely distributed $(11,13)$ and are numerous in reservoirs. These bacteria, like others from that family, have not been obtained in pure culture.

The species differentiation of Siderocapsa is based on ecological as well as morphological characteristics such as size, cell shape, and cell number in the common capsule. It follows from Table 1, however, that there is no strict crite- rion for subdividing the genus into species on the basis of the above-mentioned characteristics. Moreover, detailed ecological observations have indicated the existence of a number of transitions between the different forms of the genus as well as a great variety of forms in water reservoirs $(5,9)$. For that reason, we have questioned the validity of considering organisms of the genus Siderocapsa as independent species on the basis of only morphological characteristics in natural environments.

\section{MATERIALS AND METHODS}

Organisms. Two strains, A and G, were isolated from water samples taken from areas of mass development of $S$. eusphaera Skuja (6) in meromictic lakes of Gek-Gel in Azerbaijan and Okha-Lampi in Karelia. These strains have been deposited in the All-Union Collection of Microorganisms and assigned the numbers BKM-B N 1122 and BKM-B N 1123, respectively.

Media. The bacteria were isolated with and cultured in Pringsheim medium (18) with the following modifications: $0.002 \% \mathrm{MnSO}_{4} \cdot 4 \mathrm{H}_{2} \mathrm{O}, 0.005 \%$ yeast extract (Difco), 1 liter of distilled water, and 1\% agar (Difco); 0.1\% agar was added to liquid media. In some cases, $\mathrm{FeS}$ was applied to the bottom of test tubes or ferrous oxalate was placed in test tubes with liquid media under sterile conditions. Exposed, 
TABLE 1. Differentiating characteristics of Siderocapsa species

\begin{tabular}{|c|c|c|c|c|c|c|}
\hline No. & Species & Cell shape & $\begin{array}{l}\text { Cell } \\
\text { size } \\
(\mu \mathrm{m})\end{array}$ & $\begin{array}{l}\text { Cell no. } \\
\text { per } \\
\text { capsule }\end{array}$ & $\begin{array}{c}\text { Capsule } \\
\text { diameter } \\
(\mu \mathrm{m})\end{array}$ & Reference \\
\hline 1 & \multirow[t]{4}{*}{ S. treubii } & Cocci & $0.4-0.6$ & $1-8$ & \multirow[t]{2}{*}{$5-18$} & 13 \\
\hline $1 \mathrm{a}$ & & Paired cocci & $0.6-1.6$ & $1-36$ & & 9 \\
\hline \multirow[t]{2}{*}{$1 \mathrm{~b}$} & & Cocci and rods & $0.4-1.5$ & $1-24$ & $5-20$ & 5 \\
\hline & & & $0.8-2.4$ & & $4.5-18$ & \\
\hline \multirow[t]{2}{*}{2} & \multirow[t]{2}{*}{ S. major } & \multirow[t]{2}{*}{ Rods } & $0.7-1.8$ & $2-100$ & \multirow[t]{2}{*}{$5-28$} & 14 \\
\hline & & & $0.4-1$ by 2 & $2-30$ & & 9 \\
\hline 3 & S. monoica & Cocci & $0.5-0.75$ & 1 & & 16 \\
\hline 4 & S. coronata & Cocci & 1.2 & $2-8$ & 24 & 19 \\
\hline $4 a$ & $\begin{array}{l}\text { S. coronata subsp. } \\
\text { minor }\end{array}$ & Cocci & $1-1.2$ & $1-4$ & Smaller & 23 \\
\hline 5 & S. botryoides & Cocci & $0.6-0.8$ & $\geq 1$ & & 1 \\
\hline 6 & S. eusphaera & Cocci & $1-2$ & $1-60$ & $10-50$ & 21 \\
\hline 7 & S. geminata & Roundish or oval & $\begin{array}{l}0.5 \text { by } \\
0.5-0.8\end{array}$ & $1-2$ & $7-11$ & 22 \\
\hline 8 & S. eusphaera & Cocci & $1.6-2$ & $1-60$ & $7-10$ & 6 \\
\hline 9 & $\begin{array}{l}\text { S. eusphaera strain A } \\
\text { from Okha-Lampi } \\
\text { Lake }^{\prime \prime}\end{array}$ & Cocci or oval rods & $1-1.5$ & $1-7$ & $5-10$ & $\begin{array}{l}\text { Present } \\
\text { paper }\end{array}$ \\
\hline 10 & S. anulata & Cocci & $0.3-0.5$ & $1-2$ & & 11 \\
\hline
\end{tabular}

"In culture; otherwise in naturally occurring material.

submerged glass slides $(4,10,16)$ were employed for morphological investigation with a light microscope. The iron-containing agar medium was used by applying a thick suspension of ferrous oxalate and placing a very thin layer of the medium on top. The inoculation was made on the surface of the agar. To elucidate certain physiological features, we cultivated the bacteria on standard nutrient media (20) at $28 \mathrm{C}$.

Electron microscopy. Cell suspensions from solid or liquid media supplemented with manganese or iron were applied to colloidal film-covered grids that had been prestabilized with carbon. The suspensions were fixed in formaldehyde vapor for $20 \mathrm{~min}$, and the excess moisture was then removed. Cells grown on manganese-free media were negatively stained with 0.5 to $1.0 \%$ phosphotungstic acid.

Chemical analyses. $\mathrm{Mn}^{2+}$ was determined colorimetrically, by the formaldoxime method (8), from culture samples prefiltered through a membrane filter $\left(0.23-\mu \mathrm{m}\right.$ pore width). Total $\mathrm{Mn}\left(\mathrm{Mn}^{4+}\right.$ and $\mathrm{Mn}^{2+}$ ) was assayed by the same method but without preliminary filtration.

\section{RESULTS}

Isolation of pure cultures. Inoculation of Pringsheim medium with lake water samples resulted in the growth of small, dark brown colonies (Fig. 1b). They consisted of a mixture of cocci with large capsules, which contained deposits of manganese oxides, and of rods with colorless capsules. The shape and size of both cells and capsules in the culture were identical to those observed in lake water samples from areas of mass development of iron bacteria (6). They correspond to the description of $S$. eusphaera Skuja. From $S$. eusphaera enrichment cultures from lake water, two bacterial strains were isolated by serial dilution. For a long time, we failed to obtain growth of coccal forms without rods and considered the latter to be contaminants. Later, when observing the morphology of these bacteria, we found that the rodlike forms disappeared in old cultures, particularly on solid media, and that all of the cells acquired a coccal shape. Thus, the pure cultures proved to be pleomorphic and contained coccus- or rodlike cells, a characteristic feature of Arthrobacter species.

Morphology. Microscopy observations of the development of single cells in a double Ushaped Peshkov chamber (17) revealed a complicated developmental cycle similar to that of members of the genus Arthrobacter. Figure 2 

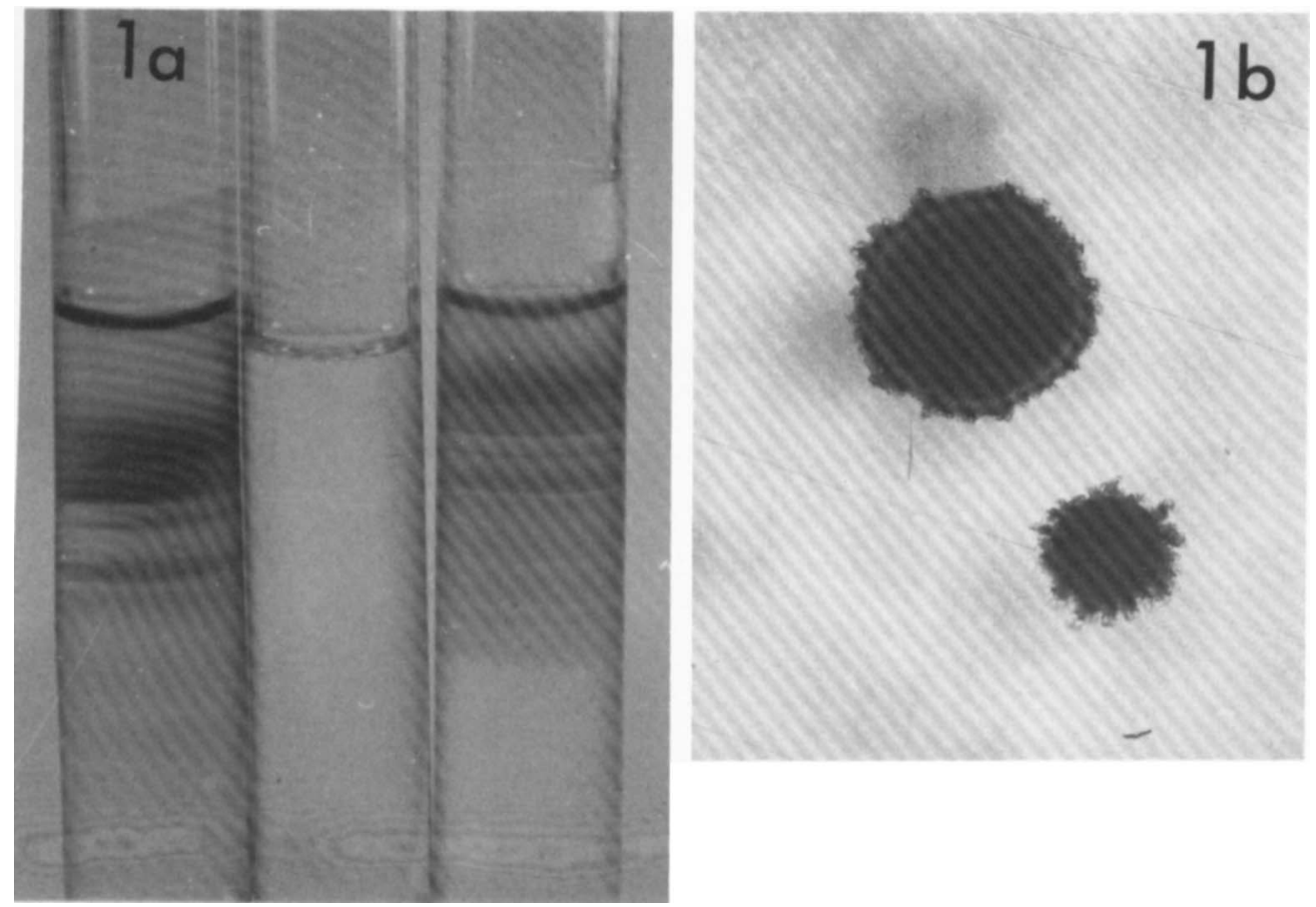

FIG. 1. Growth of S. eusphaera (Arthrobacter sp. A) on liquid (a) and solid (b) medium with $\mathrm{MnSO}_{4}$.

presents the morphological growth pattern of S. eusphaera strain A on solid Pringsheim medium without manganese. In this case, manganese oxides interfered with our observations by masking the cells. In inocula from old cultures, all cells were coccoid. When reinoculated into fresh medium, the cocci quickly grew into rods and within 12 to $16 \mathrm{~h}$ grew without division into long filaments. These filaments then broke up into rod-shaped cells and had completely disappeared after 20 to $24 \mathrm{~h}$. In the stationary phase, the rods divided to form cocci interconnected as pairs or groups of several cells. Also, rods sometimes swelled to form large cells up to $7 \mu \mathrm{m}$ in diameter, comparable to the socalled cystites (2).

Oval-shaped cells and those showing false branching, the so-called V-shaped Arthrobacter arrangements, were also present at times in our cultures. Growth on deficient agar was not accompanied by formation of filaments; during log-phase growth the culture consisted of rods, and in the stationary phase the culture consisted of cocci or a mixture of both forms.

Both strains have large capsules which, as has been shown for other bacteria (12), are lacking or are of minimal size in young cells and attain maximal size in cocci during the stationary phase of growth (Fig. 3). Cells of both strains are motile and lophotrichous or contain polar flagella (Fig. 3b and 4; Table 2).

Pattern of manganese oxide deposition. Manganese oxides are deposited in the capsules of these bacteria. Deposition begins near the end of the exponential phase and occurs first on the cell surface. Later, the entire capsule becomes encrusted so that the cell is completely masked (Fig. 5). Manganese oxide was deposited primarily on the coccal capsules and to a lesser extent on rodlike cells. Capsular encrustation appeared to hinder the liberation of daughter cells after division, probably because of a decreased capsular elasticity. As a result, coccal cells formed by rod fragmentation remained enclosed by a common capsule, thus giving rise to the cenobia so characteristic of Siderocapsa.

The study of manganese oxidation relative to the developmental stage of the culture has demonstrated that oxidation begins at the end of the exponential phase when rodlike cells are transformed into cocci. The amount oxidized is proportional to the number of cocci (Fig. 6).

Deposition of ferric oxides. In addition to oxidizing manganese, both Siderocapsa strains oxidize iron and accumulate ferric oxides in their capsules. The external appearance of ferric oxide-encrustated cells differs from cells 


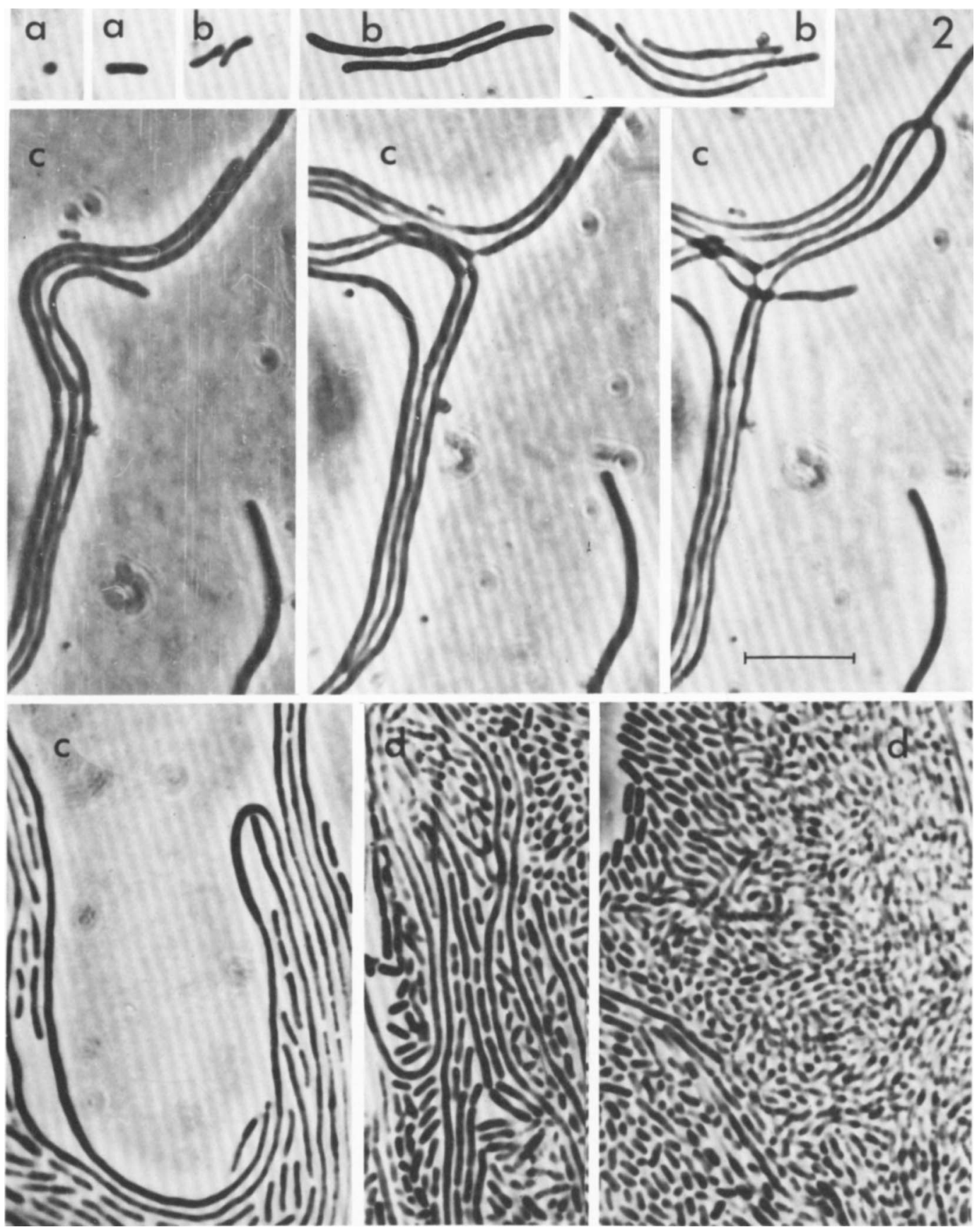

FIG. 2. Morphological variation of S. eusphaera (Arthrobacter sp. A) cells observed in a double U-shaped chamber on manganese-free medium. Observation time: (a) 0 to 6 h after inoculation; (b) 10 to $14 \mathrm{~h}$; (c) 12 to 20 $h ;(d)>72 h$. Bar represents $10 \mu \mathrm{m}$.

grown on manganese-containing medium and depends on the source of iron added. In an FeScontaining medium, capsules were less pro- nounced while oxides were deposited around young, rodlike cells as a distinct layer in a torus-like manner, thus preserving the con- 


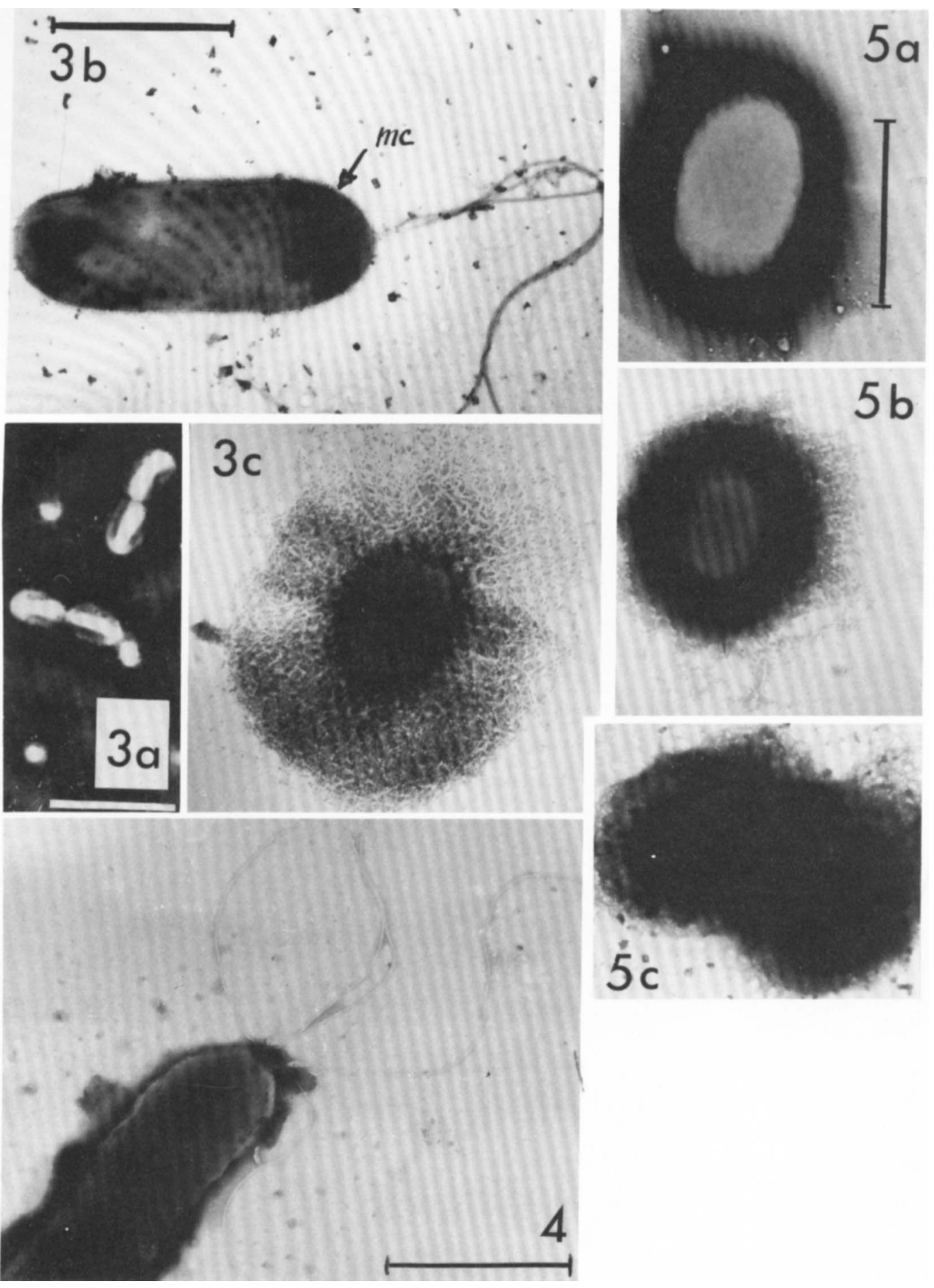

FIG. 3. Capsules of $S$. eusphaera (Arthrobacter sp. A) cells: (a) on manganese-free medium; inverse microscope; bar represents $10 \mu \mathrm{m}$; (b) during exponential phase; bar represents $1 \mu \mathrm{m}$; (c) during stationary phase; $\times 10$.

FIG. 4. Flagellated cells of S. eusphaera strain A (Arthrobacter sp. A); electron micrograph. Bar represents $1 \mu \mathrm{m}$.

FIG. 5. Forms of manganese oxide depositions of S. eusphaera (Arthrobacter sp. A) capsules: (a) beginning of oxide deposition in the inner capsular layer; (b) oxides permeate the entire capsule; (c) oxides completely mask the cell. Bar represents $1 \mu \mathrm{m}$. 
TABLE 2. Morphological characteristics of strains $A$ and $G$

\begin{tabular}{ccccccc}
\hline \multirow{2}{*}{ Strain } & \multicolumn{3}{c}{ Size $(\mu \mathrm{m})$} & & Flagellation & $\begin{array}{c}\text { Presence } \\
\text { of } \\
\text { capsule }\end{array}$ \\
\cline { 2 - 5 } & Rods & Cocci & Capsule & & Polar lophotrichous & + \\
A & $1 \times 2$ & $1-1.5$ & $5-7$ & & Polar lophotrichous & + \\
\hline
\end{tabular}

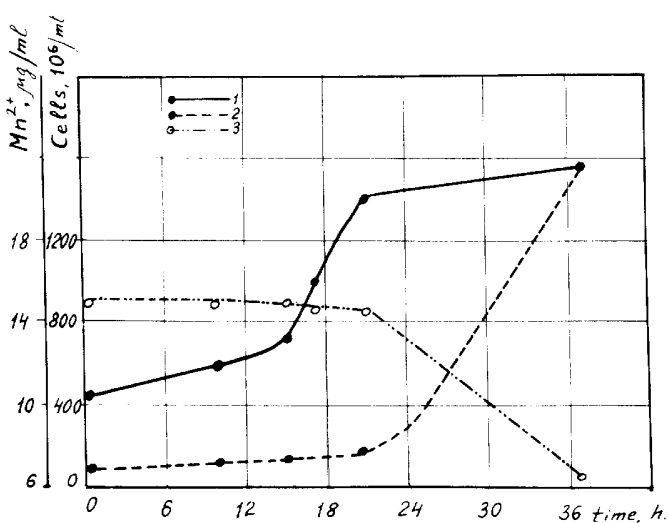

FIG. 6. Manganese oxidation in the medium as related to the developmental phase of $S$. eusphaera (Arthrobacter sp. A): (1) total number of cells; a rod is arbitrarily taken to be equal to two coccal cells; (2) number of cocci; (3) $\mathrm{Mn}^{2+}$.

tours of the cells. (A torus is a marginal thickening of a thin capsule resembling the link of a chain or, if incomplete, a horseshoe.) On a medium with ferrous oxalates, oxides were distributed more uniformly in the capsule (see Fig. 12c).

Morphological similarity of S. eusphaera strains $A$ and $G$ to members of the family Siderocapsaceae. Cell size, shape, and number inside a common capsule vary considerably (Fig. 7). Cells may be coccoid, oval, or rodshaped and number one, two, four, or more within a single capsule. Coccal cells correspond to descriptions of $S$. eusphaera Skuja (Fig. 8, 11 ), with large numbers of cells appearing in older cultures. Zoogleic aggregates were formed in liquid media (Fig. 7); the coccal or oval cells were not uniformly distributed and were quite similar to $S$. major Molisch (Fig. 9). Occasionally, capsules appeared to be encrusted with oxides, having empty "sockets," characteristic of S. treubii Molisch (Fig. 10a). The capsules surrounding a group of cells also formed a colony or chain, corresponding to descriptions of $S$. coronata Red.

On FeS-containing media, cells have distinct thin capsules that preserve cell outlines, as observed in Ferribacterium (3), Naumanniella pygmaea (1), and members of the genus Sideronema when oval cells predominate (Fig. 12).
The above-mentioned structures may be attached to the slides submerged in the medium and appear to be identical in this respect to the attached forms of Siderocapsa seen in natural habitats.

Physiological and cultural properties. Strains A and G grow on most standard bacte-

Both strains are characterized by the following properties. On Pringsheim medium, colonies become opalescent on days 2 to 3 and later become brown-colored owing to deposition of manganese oxides. Colony diameter is about 2 to $3 \mathrm{~mm}$. On a medium with ferrous oxalate, colonies are orange in color because of ferric oxide deposits. On meat-peptone agar, colonies are yellowish-gray and attain a diameter of 10 $\mathrm{mm}$. When the cultures become old, the colonies are flat with an even margin and are smooth, and the medium turns yellowishgreen. Rods and cocci are gram negative; cystites are gram variable.

Both strains grow on minimal agar, forming surface colonies up to $1.0 \mathrm{~mm}$ in diameter after 2 to 3 days of growth.

When cultivated in liquid Pringsheim medium with $0.1 \%$ agar, strain $\mathrm{A}$ forms a film 1 to $1.5 \mathrm{~cm}$ from the surface of the medium, where the oxygen concentration is $0.1 \mathrm{mg} / \mathrm{liter}$, indicating an ability to grow under microaerophilic conditions. The bacteria are incapable of developing anaerobically with $\mathrm{NO}_{3}{ }^{-}$. On media with glucose, galactose, or arabinose, there is acidification but no gas formation, and neither gas nor acid is produced from maltose, fructose, sucrose, lactose, or raffinose. It is of importance that both strains produce catalase. Strain G is capable of utilizing sodium acetate as the sole source of carbon. The $\mathrm{G}+\mathrm{C}$ content of strain $\mathrm{A}$ is $60.8 \pm 0.5 \mathrm{~mol} \%$.

According to their morphological, cultural, and physiological properties, strains $A$ and $G$ belong to the genus Arthrobacter of the family Corynebacteriaceae Cohn and Dimmick (2).

Comparison of the isolated strains with species of the genus Arthrobacter. Strains A and G were compared with Arthrobacter globiformis BKM 661, A. citreus BKM 654, A. simplex BKM 667, and A.tumescens BKM 807 regarding morphology and the ability to oxidize manganese and iron. All of the above-men- 

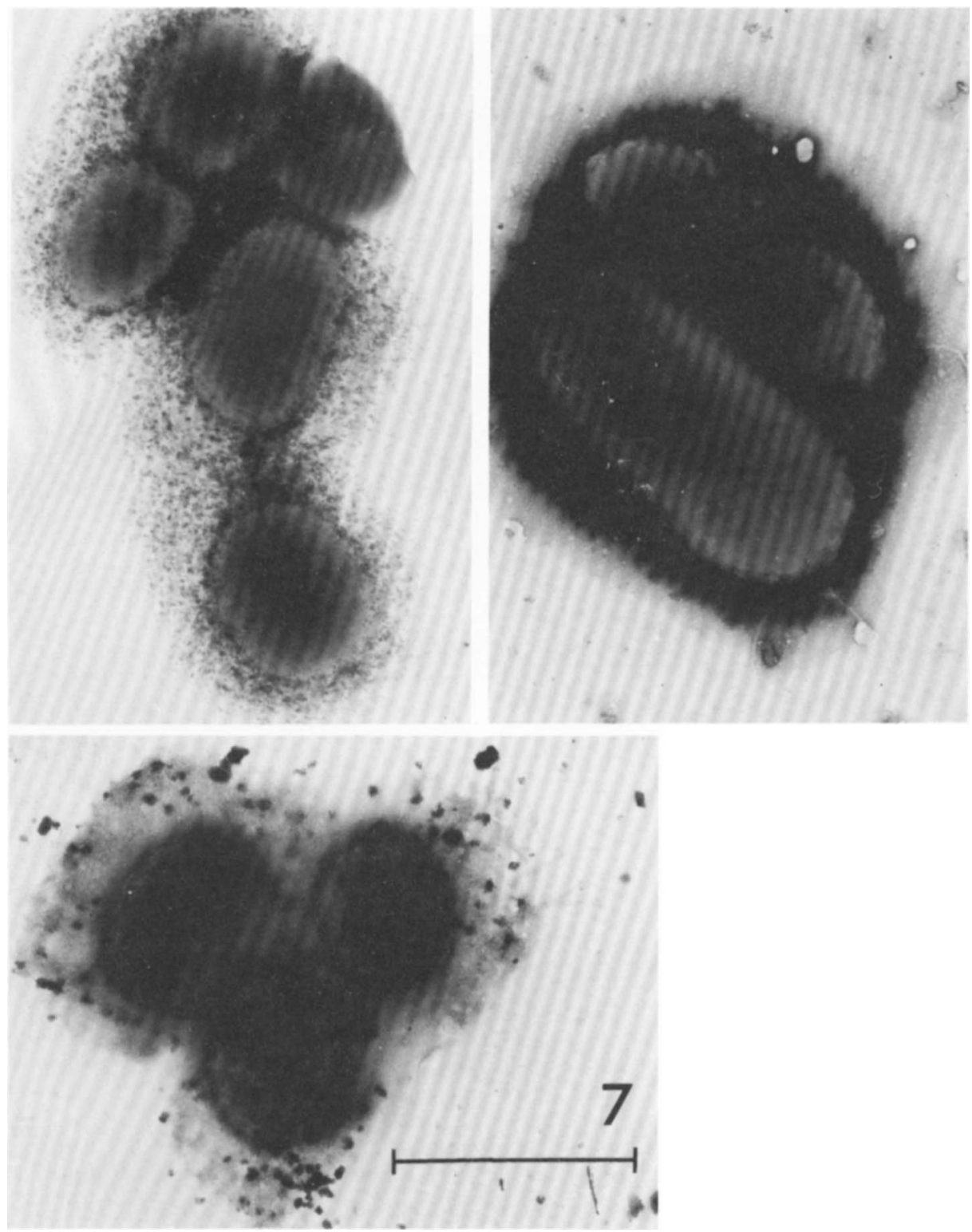

FIG. 7. Variation of shape, size, and aggregation of S. eusphaera (Arthrobacter sp. A) cells. Bar represents $1 \mu \mathrm{m}$.

tioned species grow on Pringsheim medium with $\mathrm{MnSO}_{4}$ or FeS. All of the species except $A$. tumescens oxidize manganese under these conditions, and all four oxidize iron, depositing oxides in the capsules. Morphologically, the cells of these species do not differ from those of strains $\mathrm{A}$ and $\mathrm{G}$, except that $A$. simplex forms smaller cocci $(0.6$ to $0.8 \mu \mathrm{m}$ in size) (Fig. 13). When grown in test tubes with liquid medium, they produce growth zones in the form of a ring somewhat immersed in the medium. On solid media with manganese, brown colonies develop with $\mathrm{MnO}_{2}$ deposits. It should be noted that in both the culture collection strains of Arthrobacter species and in the A and G strains the functioning of manganese oxidation is sometimes weak but is restored upon further subculturing. This property appears to be associated with the activity of certain physiological processes responsible for manganese oxidation 

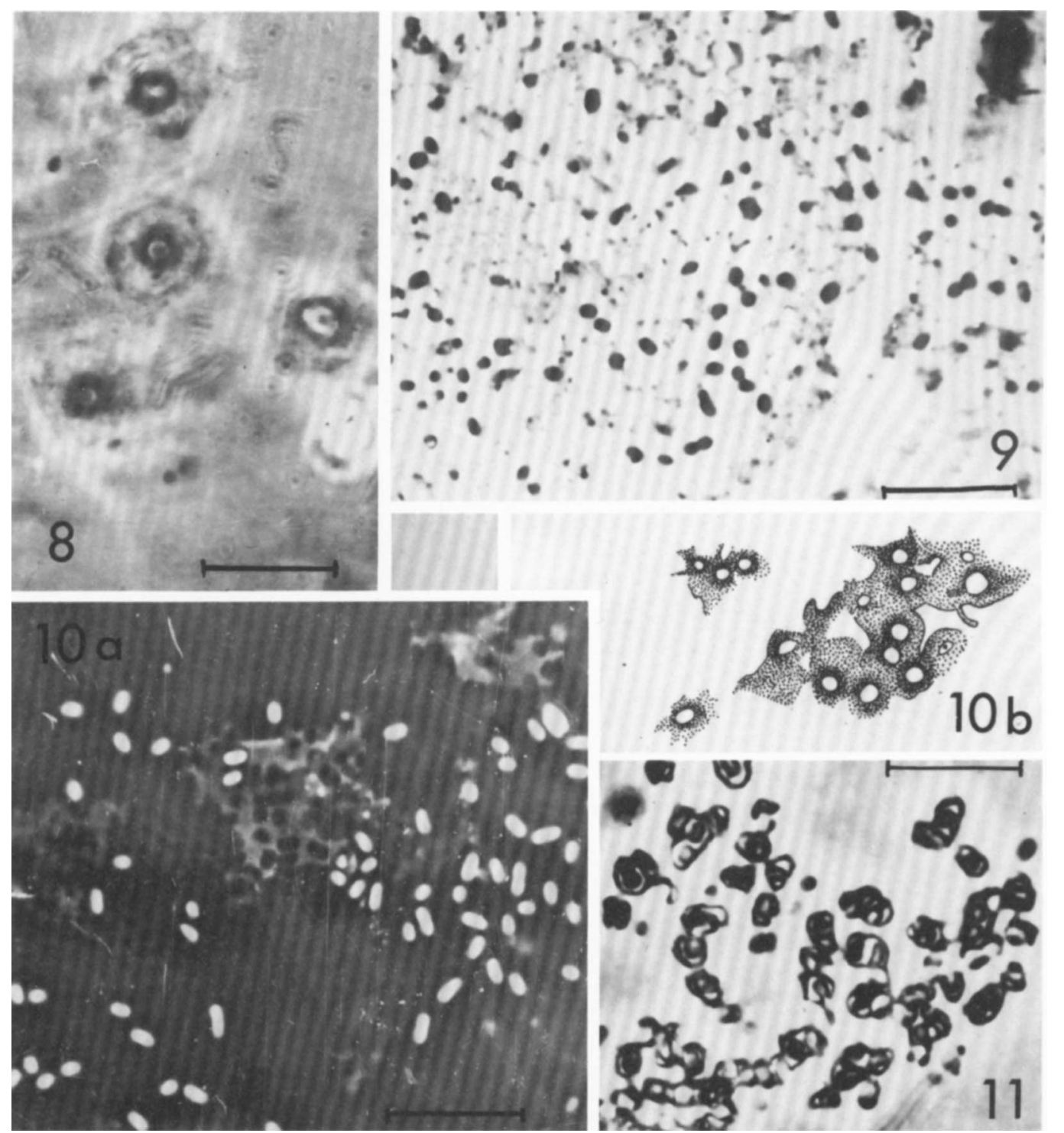

FIG. 8-11. Morphology of S. eusphaera (Arthrobacter sp. A) analogous to structures characteristic of other species of Siderocapsa. Bar represents $10 \mathrm{\mu m}$.

FIG. 8. S. eusphaera (Arthrobacter sp. G) from lake water on membrane filter.

Fig. 9. S. major type.

FIG. 10. (a) S. treubii type; (b) same but according to Molisch (14).

FIG. 11. S. eusphaera type.

and is more marked in A. globiformis than in the two other species.

It is important to emphasize the presence of large capsules in the strains of all species of Arthrobacter studied.

\section{DISCUSSION}

A morphological study of strains A and G has shown that they belong to the genus Sidero- capsa. The morphological variation found in pure cultures, however, exceeds the species differences in members of the genus Siderocapsa and related species of the family Siderocapsaceae (Siderobacter, Sideronema, Ferribacterium, and, partly, Naumanniella). During growth in an iron-containing medium, they produce morphological forms of growth correspond- 


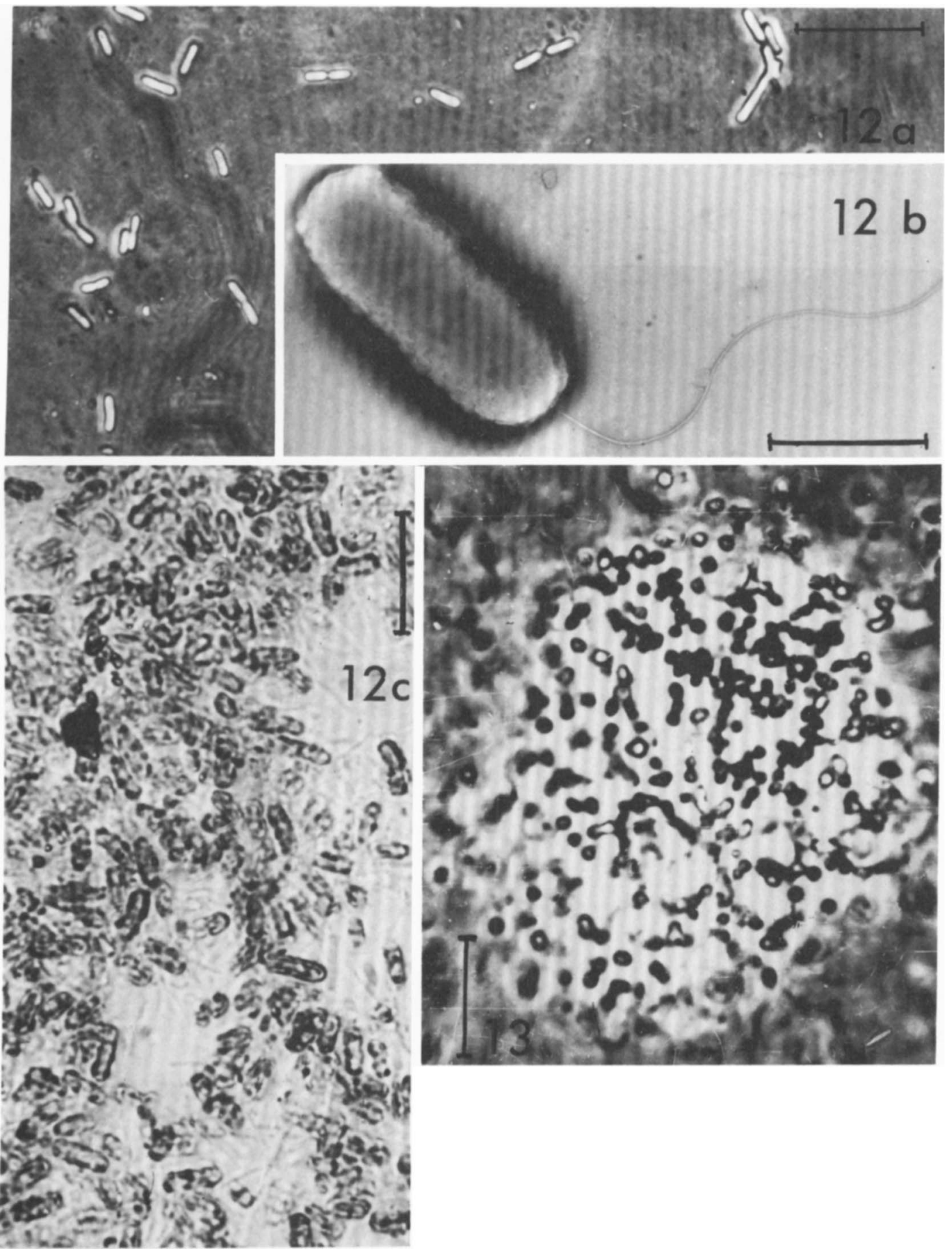

FIG. 12. Morphology of cells of S. eusphaera strain A on an FeS-containing medium $(a, b)$ and from the surface of an Mn-containing medium (c). Cells resemble those of Sideromonas $(a, b)$ and Naumanniella (c). Bar represents $10 \mu \mathrm{m}(a, c)$ or $1 \mu \mathrm{m}(b)$.

FIG. 13. Arthrobacter simplex (BKM-B-554) on an FeS-containing medium. 
ing to those of the species in the above-mentioned genera. This precludes differentiation of growth forms of Siderocapsa in naturally occurring material into separate species, as well as differentiation of members of the family into the above-mentioned genera on the basis of common characteristics.

Studies of the developmental cycles and of cultural/physiological characteristics of the strains studied make it possible to ascribe them to the genus Arthrobacter, family Corynebacteriaceae. With respect to the capacity for iron and manganese oxidation, they are also identical to the type species, A. globiformis.

Our isolates differ from known species of $\mathrm{Ar}$ throbacter in some morphological, cultural, and physiological features. The isolates, strains A and $\mathrm{G}$, therefore, must be regarded as members of a new species, and the name Arthrobacter siderocapsulatus is proposed. A more detailed description and the taxonomy of this organism will be published elsewhere (24).

The deposition of metal oxides both in strains A and G and in Arthrobacter species is associated with the capsule. Although there is no mention in the literature that Arthrobacter cells are surrounded with capsules, the capsules themselves are visible in numerous photomicrographs. Moreover, chemical analyses reveal large amounts of extracellular polysaccharides in Arthrobacter cultures (15). Capsules analogous to those of strains $A$ and $G$ have been found by us in culture collection strains of $\mathrm{Ar}$ throbacter.

The ability of $A$. globiformis, the type species of Arthrobacter, to grow on media with a low organic-matter content and to oxidize manganese supports the proposal that our strains be ascribed to the genus Arthrobacter. Manganese and iron oxidation appears to be a rather widespread property of members of that genus. Ehrlich (7) also isolated a manganese-oxidizing Arthrobacter species but did not pay sufficient attention to the morphology of his culture.

Based on morphogenesis in the ArthrobacterSiderocapsa group, some contradictory data relative to Siderocapsa morphology may be explained. The presence in the same microcolony of both large rods and cocci, as in the case of Siderocapsa major, or of a variety of cell sizes, as in Siderocapsa treubii, under various environmental conditions is obviously explainable.

Furthermore, the distribution of morphological types of Siderocapsa appears to be dependent on the trophic category of each particular lake habitat. In pure cultures in organic nitrogen deficient-media, coccoid cells predominate. However, rodlike cells do occur, especially in organic nitrogen-rich media. Thus, our data explain many ecological observations of other investigators $(5,10)$.

The evidence presented above warrants the conclusion that the genus Siderocapsa with its various species, as well as the entire Siderocapsaceae family, should be abolished as an independent taxonomic entity. It is proposed, therefore, that the previously described organisms of this family be considered members of the genus Arthrobacter, having morphological variability under specific environmental conditions (namely, in the presence of reduced iron and manganese compounds).

\section{REPRINT REQUESTS}

Address reprint requests to: Dr. G. A. Dubinina, Institute of Microbiology, Profsojuznaja 7a, 117312 Moscow, USSR.

\section{LITERATURE CITED}

1. Beger, H. 1949. Über Zoogloea filipendula-formen und einige Eisenbakterien. Zentralbl. Bakteriol. Parasitenkd. Infektionskr. Hyg. Abt. 1: Orig. 154:61-68.

2. Bergey's manual of determinative bacteriology, 7 th ed. The Williams \& Wilkins Company, Baltimore.

3. Brussoff, A. 1918. Über eine stäbchenförmige, kalkspeichernde Eisenbakterie aus dem Klärschlamm einer biologischen Abwasserkläranlage. Zentralbl. Bakteriol. Parasitenkd. Infektionskr. Hyg. Abt. 2 48:193-210.

4. Cholodny, N. G. 1953. Iron bacteria, p. 83-86. USSR Academy of Sciences, Moscow.

5. Drake, H. 1965. Occurrence of Siderocapsa treubii in certain waters of the Niederrhein. Gewässer Abwässer 39:40-41.

6. Dubinina, G. A., V. M. Gorlenko, and Y. I. Suleimanov. 1973. Microbiological processes of transformation of forms of sulfur, iron and manganese in the meromictic lake Gek-Gel. Mikrobiologiya 41:153.

7. Ehrlich, H. L. 1968. Bacteriology of manganese nodules. II. Manganese oxidation by cell-free extracts from manganese nodule bacteria. Appl. Microbiol. 16:197-202

8. Goto, I. I. 1962. Rapid colorimetric determination of manganese in water containing iron. Anal. Chem. Acta 27:331-334.

9. Hardman, J., and A. T. Henrici. 1939. Studies of freshwater bacteria. V. The distribution of Siderocapsa treubii in some lakes and streams. J. Bacteriol. 37:97-106.

10. Henrici, A. T., and D. A. Johnson. 1935. Studies of freshwater bacteria. II. Stalked bacteria, a new order of Schizomycetes. J. Bacteriol. 30:61-88.

11. Kalbe, D. L., R. A. Keil, and M. Thiele. 1965. Lichtund elektronenmikroskopische Studien an Arten von Leptothrix, Siderocapsa und Planctomyces. Arch. Protistenkd. 108:29-40.

12. Meynell, G. G., and A. M. Lawn. 1965. Inheritance of capsule and the manner of cell-wall formation in Bacillus anthracis. J. Gen. Microbiol. 39:423.

13. Molisch, H. 1910. Siderocapsa treubii Molisch, eine neue weitverbreitete Eisenbakterie. Ann. Jahrb. Buitzenzorg. 5:29.

4. Molisch, H. 1910. Die Eisenbakterien. G. Fischer, Jena.

15. Mulder, E. G., M. H. Deinema, W. L. van Veen, and L.P.T.M. Zevenhuizen 1968. Polysaccharids, lipids 
and poly- $\beta$-hydroxybutyrate in microorganisms. Rec. Trav. Chim. Pays-Bas 81:797-819.

16. Naumann, E. 1921. Untersuchungen über die Eisenorganismen Schwedens./Kgl. Sven. Vetenskaps Akad. $1: 32$.

17. Peshkov, M. A. 1955. Cytology of bacteria, p. 17-18. USSR Academy of Sciences, Moscow.

18. Pringsheim, E. G. 1949. Iron bacteria. Biol. Rev. Cambridge Philos. Soc 24:200-245.

19. Redinger, F. 1931. Siderocapsa coronata Redinger, eine neue Eisenbakterie aus dem Lunzer Obersee. Arch. Hydrobiol. 22:410-414.

20. Skerman, V. B. D. 1967. A guide to identification of the genera of bacteria, 2nd ed. The Williams \& Wilkins Company, Baltimore.

21. Skuja, H. 1948. Taxonomie des Phytoplanktons einiger Seen in Uppland, Schweden. Symb. Bot. Ups. 9:1399.

22. Skuja, H. 1956. Taxonomische und biologische Studien das Phytoplanktons Schwedischer Binnengewässer. Nova Acta Regiae Soc. Sci. Ups. Ser. IV 16:1-404.

23. Warwick, F. 1963. Planktonorganismen aus waldviertler Fischteichen II. Arch. Protistenkd. 106:369-377.

24. Zhdanov, V. A., and G. Dubinina. 1975. Arthrobacter siderocapsulatus isolated from lake water. Microbiologiya 44:714-719. 